\title{
Matteus 28:19-20: Enkele tekskritiese en eksege- tiese opmerkings aan die hand van Nestle-Aland se 27 e uitgawe van die Griekse Nuwe Testament
}

\section{J M Ras \\ Universiteit $\operatorname{van}$ Zoeloeland}

\begin{abstract}
Some text-critical and exegetical remarks on Matthew 28:19-20, based on the 27th edition of Nestle-Aland's Greek New Testament In this study a few text-critical and exegetical remarks on Matthew 28: 19-20 are made, based on the recent publication of the 27th edition of Nestle-Aland's Greek New Testament. These remarks are made in the light of the immediate context of Matthew 28:19-20 and in the light of the included textual variants that exist in this edition. An attempt has been made to make these exegetical information relevant to readers $l i$ ving in the twentieth century.
\end{abstract}

\section{INLEIDING}

Matteus 28:19-20 is seker die bekendste sendingverse in die Nuwe Testament. Gelowiges wat die gedagte van 'n 'uitbeweeg' na die heidenvelde in hulle hart koester, en dit 'mentaal-deikties' visualiseer en 'seloties' propageer, praat van 'the Great Commission' as daar na dié verse verwys word (vgl Morris 1992:743; Powell 1995:22; Waetjen 1976:255). Omdat talle gelowiges dié teksgedeelte losmaak uit die oorspronklike konteks waarin dit moontlik ontstaan het, ${ }^{1}$ en daar normaalweg geen ernstige poging is om dit in die lig van sy bepaalde Sitz im Leben ${ }^{2}$ te verstaan nie, word hierdie gedeelte baie keer sommer op lukrake wyse direk op die twintigste eeu van toepassing gemaak en dikwels gevoelvol ${ }^{3}$ en met passie verkondig en gepredik.

Vanuit 'n histories-kritiese invalshoek is dit egter baie duidelik vir Nuwe Testamentici dat dié verse nie sommer direk aan die historiese Jesus verbind kan word nie. Ons kan met ander woorde nie net sommer sê dat ons nou ongetwyfeld met die ipsissima verba Jesu werk nie. Trouens, wat die 'werklike Jesus'4 nou eintlik alles gesê het, bly uiteraard nog 'n ope vraag waarmee al lank geworstel word, 5 en wat in die tyd wat kom, sekerlik ook nog lank die aandag van geleerdes sal gevange hou.

* Hierdie artikel word sonder redaksionele wysigings geplaas. 
Versigtigheidshalwe sal mens moet sê dat hierdie gedeelte (net soos die res van die Matteusverhaal) 'relatief' is omdat ons hier te make het met 'n 'selektief-geinterpreteerd-gekombineerde' 6 teks wat op 'antropomorfe' wyse deur die outeur(s) aan die oorspronklike lesers voorgehou is. Kommunikatief gesproke was die doel skynbaar om een of ander respons by die lesers te ontlok of een of meer gedagte(s) by hulle tuis te bring (vgl Van Aarde 1994:11-13). Ten minste weet ons dat die verteller vir ons iets aangaande Jesus wou sê! Dit sal egter meer korrek (en eerlik!) wees as ons in die lig van die beskikbare tekstuele getuienisse wat ons het, probeer sê wat ons dink die teks sê. Dit beteken dat die koteks (leksikaal-sintaktiese verband) in die besonder ons aandag moet verdien, en daarmee saam ook die konteks (die histories-kulturele verband). ${ }^{7}$

In hierdie studie word tekskritiese en eksegetiese opmerkings gemaak, primêr in die lig van die onmiddellike koteks van Matteus 28:19-20 en ook aan die hand van die ingeslote teksuariante wat deur Nestle-Aland aan sy lesers voorgehou word. Daar word ook gepoog om die eksegetiese gegewens relevant en aktueel te maak vir vandag.

Die gekose Griekse lesings van die hele Matteusevangelie, insluitende hoofstuk 28 verse 19 en 20, soos gereflekteer in die teks van NA ${ }^{27}$, is gebaseer op die opstellers (B Aland, $\mathrm{K}$ Aland, J Karavidopoulos, C Martini \& B Metzger ${ }^{8}$ ) se keuse wat hulle op die volgende manuskripte gebaseer het: Papirus $1,19,21,25,35,37,44,45,53,62,64$, $67,70,71,83,86,96$, unsiaal $\mathrm{x}, \mathrm{B}, \mathrm{C}, \mathrm{D}, \mathrm{L}, \mathrm{W}, \mathrm{Z}, \boldsymbol{\theta}, 058,067,071,073,078$, 085, 087, 089, 094, 0102, 0106, 0107, 0118, 0128, 0148, 0160, 0161, 0164, 0170, 0171, 0200, 0204, 0231, 0234, 0237, 0242, 0249, 0271, 0275, 0277, 0281, 0293, 0298 en minuskels $f^{1}, f^{13}$ en 33 (vgl NA 27 1995:58*). Hierdie manuskripte is volgens Nestle-Aland 'consistently cited witnesses of the first order' (vgl NA27 1995:58*), en word verder gerugsteun deur die volgende handgeskrewe dokumente: $K, N, P, \Gamma, \Delta$, $565,579,700,892,1241,1424$ en leesroosters 844 en 2211 , wat :consistently cited witnesses of the second order', is (NA 27 1995:59*).

Die gemelde manuskripte bevat uiteraard nie almal die Matteusevangelie in toto nie, maar toon inter alia die verskeidenheid van manuskripte aan wat op eklektiese wyse in oorweging geneem is vir die komposisie van 28:19-20. 'n Vlugtige blik na die tekskritiese apparaat by verse 19 en 20 toon aan dat bekende unsiale soos $x$ (Sinaiticus) en $B$ (Vaticanus) nie altyd dieselfde teksvariante het nie en dat daar geen papirusvariante deur Nestle-Aland vermeld word nie. Omdat dié manuskripte normaalweg 'n groter gewig dra as die latere unsiale en minuskels, vanweë hulle vroeère daterings, 9 toon $\mathrm{K}$ en $\mathrm{B}$ se verskille, ascok die afwesigheid van enige papirusyariante, myns insiens tereg die relatiwiteit van die bestaande lesings aan. 'n Absolute lees en aanvaarding van die huidige tekslesing van Nestle-Aland is met ander woorde nie 'n uitgemaakte saak nie, omdat vroeēre wissellesings ontbreek en die bestaande variante verskille openbaar. 


\section{DEE ONMTDDEUIKE KOTYKS VAN MATTEUS 28:19-20}

Die Metteusvertal wond normaal weg in drie dele verdeel te wete 1:1 tot 4:16, 4:17 tot 16:20 en 16:21 tot 28:20 (vgl Garland 1993:9-10; Kingsbury 1989:40; 1995:358-377; Ras 1996:44; Van Aarde 1994:23). Alhoewel daar nie 'n censtemmige skematiese indeling vir die Matcusvertaal bestann nie, kan versigtigheidshalwe gest word dat die cerste gedeotte handel cor die bekendstelling van Jesus die Messiaskoning ann Israel, en die tweede handal weer cor die werk/bediening van Jesus. Die dende en laaste gedecite, wat ons vernelde godectite (Matt 28:19-20) inaluit, folus op Jesus se lyding, sterwe en opanding (vgl inser alia Kingebury 1989:57-59, 77; Ras 1996:45-46, 61, 138).

Mattens 28:1-20 word weer verdeel in drie selssies. Die cerste handel oor die opstandingectoure self (vv 1-10), die tweede cor die verhaal wat onder die Jode rakende die opetanding versprei is (vv 11-15), en die derde oor die verskyning van Jesus in Galilea and die of discipels (vv 16-20).10 Verse 19 en 20 wat in hiendie studie van nader belyk word mank met ander woorde deel uit van seksie 3. Dit (vv 16-20) handel meer presies cor die elf dissipels se ontmoeting met Jesus in Galilea na die opstanding.

\section{3. 'N KRITHESE BESTARTING VAN MATTEUS 28:16, 17 EN 18 WAT MET VERST 19 IN 20 VERBAD HOU}

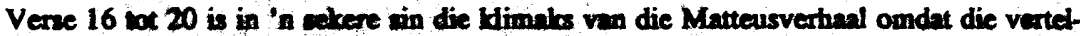

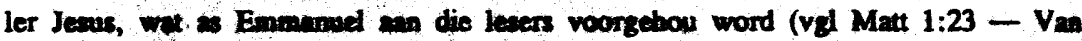
Aande 1994), op of 's wyse tats de Hy san die dissipels belowe dat Hy vir altyd net hulle ell wets of en met die voleinding ven die ceu. Die voleinding het in Mevios

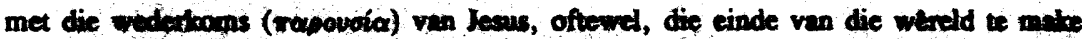
(vgl Morris 1992:149; Rat 19\%6:199-201, 231-233; Sim 1996:187; Wascon 1992:07).

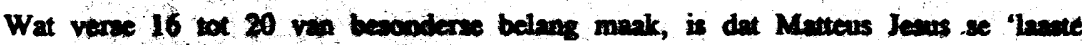
woonde' nam dio discipals hier atrots!

\subsection{Matters 2k:16}

In hierdie odeeltell noem Motteus dat die elf dissipels m Galilea gegann het, na die berg' wat Jeows bulle bestel het. Die elf (oi bybero) word vermeld, plels van die twaalf (ai cisbexo - Matt 10:2)), omdat Matteus alreeds vermeld het dat Judas wat Jesus verrai het, selfmoord geploeg het (vgl Matt 27:1-10). ${ }^{27}$ Galilea is die plek van die heidene (Matt 4:15-16), die land wat in duisternis sit.

Dit is ironies dat Matteus dit so skets dat Jesus die dissipels hiematoe laat kom het omdat die Jode gedink het dat Jerusalem met die tempel die eintlike plek van 'lig' is. Dit is egter duidelik dat Jerusalem by implikasie in duistemis sit omdat die skare daar 
'n paar dae vantevore geskreeu het dat Jesus gekruisig moes word (vgl Matt 27:20-26)! Tereg het die Lig in Galilea as 'lig' opgegaan soos Matteus sê die profeet Jesaja 'voorspel' het (Matt 4:15-16).

Die presiese berg waarheen die dissipels moes gaan is onseker. ${ }^{14}$ Interessant is dat die frase eis tò ôpos wat normaalweg as rigtingaanduidend ('na die berg') verstaan word, ook met 'in die berg' vertaal kan word. Dit sou dan prakties beteken dat die dissipels en Jesus 'n sekere 'wegkruipplek' soos 'n grot kon gehad het waar hulle al voorheen ontmoet het. Die dissipels het dan by implikasie na dié plek gegaan, en toe hulle by dié plek gekom het, het hulle 'in die berg' gegaan (èropeiv

Alhoewel Waetjen (1974:254) die woorde eis tò ôpos vertaal met 'into the mountain', lewer hy nie kommentaar oor die moontlikheid van 'n wegkruipplek nie. Myns insiens is dié opmerking insake 'n wegkruipplek nie onmoontlik nie, maar lyk dit tog hoogs onwaarskynlik omdat Matteus nie van só 'n vorige ontmoeting praat nie. Die feit is egter dat Matteus dié ontmoeting só skets dat dit moet blyk dat niemand anders behalwe Jesus en die elf dissipels daar was nie.

Opvallend in die tekskritiese apparaat van $\mathrm{NA}^{27}$ is dat daar geen tekskritiese opmerkings hoegenaamd by vers 16 voorkom of vermeld word nie. Slegs in die regterkantse kantlyn word daar teksverwysings na Markus 16:14, Lukas 24:9, 33 en Handelinge 1:26 en 2:14 gegee. Vir interessantheid kan genoem word dat 'n vergelyking met Markus 16:1415 aantoon dat Jesus aan die elf dissipels in Galilea verskyn het, by implikasie toe hulle aan tafel was. ${ }^{16}$ Die verwysings na Lukas 24:9 en 33 toon dat Jesus die elf dissipels in Jerisalem gesien het, en Handelinge 1:26 en 2:14 vermeld slégs soos Matteus 28:16 die 'elf dissipels'.

\subsection{Matteus 28:17}

Matteus noem hier dat toe die dissipels Jesus gesien het, het hulle Hom aanbid, maar sommige ${ }^{17}$ het getwyfel. Unsiale Alexandrinus (5e eeu $\mathrm{nC}$ ), Washingtonensis (5e eeu $\mathrm{nC}$ ), Koridethi ( $9 \mathrm{e}$ eeu $\mathrm{nC}$ ), en 0148, sowel as teksfamilies 1, 13 en die Meerderheidsteks het ook die lesing aivr aanbid het.

Alhoewel die tekslesing van Nestle-Aland dié woord weglaat omdat die ouer unsiaallesings van inter alia kodekse Alef (4de eeu $\mathrm{nC}$ ), Vaticanus (4e eeu $\mathrm{nC}$ ) en BezaeCantabrigiensis (5de eeu $\mathrm{nC}$ ) dit uitlaat, is dit kotekstueel duidelik dat die dissipels vir Jesus aanbid het. Gevolglik neig die lesing 'vir Hom' om eerder meer verduidelikend en meer presies, as problematies en teenstrydig met die tekstrant en betoog van die verteller te wees. 


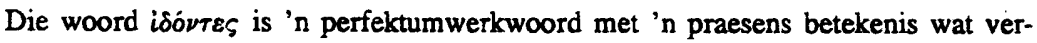

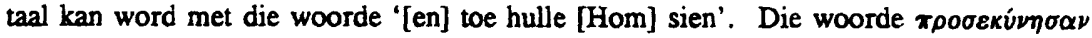
en $\dot{\delta} i \sigma \tau \alpha \sigma \alpha \nu$ is albei aoristuswerkwoorde wat in die indikatiewe en aktiewe vorm is. Dit beteken dat dit kotekstueel as 'n feit gestel word dat die elf dissipels volgens die verteller Jesus werklik aktief aanbid het, maar dat sommige onder hulle ook werklik aktief getwyfel het.

Waarom die dissipels getwyfel het, word nie deur Matteus vermeld nie. Terwyl Waetjen (1976:255-257) niks van die 'getwyfel' noem nie, wil Nielsen (1974:188) dit eerder as 'n 'aarsel' sien. Morris (1992:744-745) praat van 'hesitated'. Nielsen (1974:189) noem egter nie hoekom daar 'geaarsel' is nie. Die teenwoordigheid van die

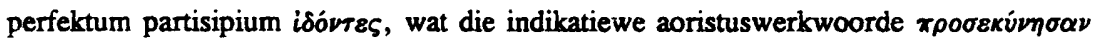
en $\dot{\delta} \delta i \sigma \tau \alpha \sigma \alpha \nu$ voorafgaan, toon vanweẽ die partisipium se ondergeskikte posisie aan dat die aanbidding en twyfel met die 'sien van Jesus' verband hou.

Dit kan wees dat sommige van die dissipels getwyfel het of Jesus werklik dood was, of dit werklik Hy is, of dit kon wees dat hulle gedink het dat hulle slegs ' $n$ gesig sien, of Matteus kon dit doelbewus só vermeld het om die 'feilbaarheid' van die mens (d w's dat die mens ook kan 'twyfel') te beklemtoon. Jesus se voorkoms kon uiteraard ook 'vreemd' gewees het (vgl o a Morris 1992:745). Dit is egter redelik voor die hand liggend dat die tviyfel met die opstanding moet verband hou (vgl Son 1983:65). Venter (1991:111) sê dat twyfel 'n Matteusmotief is waarteen die dissipels moet 'waak'. Dit is egter opvallend in hierdie gedeelte van Matteus se verhaal dat daar nie staan dat die dissipels 'gevrees' het nie (vgl Matt 28:4-5, 8 10; Mk 16:8)!

\subsection{Matteus 28:18}

Vers 18 noem dat Jesus nadergekom ( $\pi \rho 0 \sigma \varepsilon \lambda \theta \dot{\omega} \nu$ ) en met hulle gespreek het. Dit impliseer dat Matteus wil sê dat Jesus nie fisies té naby die dissipels was nie - Hy het nader na hulle toe beweeg! Die voorsetsel $\pi \rho \circ \varsigma$ is rigtingaanduidend en druk semanties die gedagte uit dat iemand 'na 'n mens toe kom' om by implikasie 'teenwoordig te wees'. Aangesien die woord wat gebruik word $\pi \rho 0 \sigma \varepsilon \lambda \theta \dot{\omega} \nu$ is, en nie $\dot{\alpha} \nu \eta \lambda \theta \bar{\omega} \nu$ (van $\alpha \nu \alpha+\check{\varepsilon} \rho X \rho \mu \alpha \iota)$ of $\kappa \alpha \tau \eta \lambda \theta \hat{\omega} \nu$ (van $\kappa \alpha \tau \alpha+\check{\varepsilon} \rho \chi 0 \mu \alpha \iota)$ nie, toon dit myns insiens dat Matteus dit nie wou beklemtoon het dat Jesus na die dissipels 'opgegaan' of 'afgegaan' het nie. Dit word slegs vermeld dat $\mathrm{Hy}$ "na hulle toe gekom het."

Verse 18 tot 20 bevat Jesus se 'laaste woorde' aan sy dissipels. Omdat Matteus regdeur sy evangelie Jesus as Emmanuel, God-met-ons, aan die dissipels en die lesers voorgehou het, is hierdie laaste gesprek van besonderse belang. Hierdie 'laaste woorde' wat in vers 18 begin en in vers 20 eindig, laat mens tereg aan die moderne be- 
grip, 'testament', dink - sy laaste wil! Hierdie 'laaste woorde' kan myns insiens breedweg op drie wyses getipeer word, te wete 'n 'verklaring' ( $v$ 18), 'n 'opdrag' (v 19) en 'n 'versekering' ( $v 20$ ).

Die 'statement' of verklaring in vers 18 is dat Matteus sê dat Jesus aan die elf dissipels (Matt 28:16) genoem het dat aan Hom alle mag in die hemel en op aarde gegee is. Die aoristus isón ('Hy het gegee') is konstatief en reduseer dié opmerking tot 'n

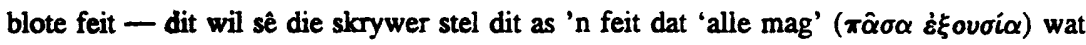
in die hemei en op die aarde is aan Jesus gegee is. In die verderliggende koteks (Matt 11:27) is dit duidelik dat dit God die Vader is wat aan Jesus dié mag gegee het. Jesus is immers God se Seun wat gekom het om God se volk van hulle sondes te verlos (Matt 1:21) en Sy Vader se dinge te kom bedink (Matt 16:23).

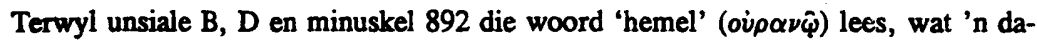
tief enkelvoud is, het kodeks D 'hemele' (oijowous), die datief meervoudsvorm. Dit is onseker waarom Nestle-Aland (1995:87) in albei gevalle kodeks D noem terwyl ons hier met twee verskillende lesings te make het. 'n Mens verwag eerder dat die cen lesing byvoorbeeld $D^{*}$ of $D^{1}$ sal wees. Dit is egter moontlik dat ons hier met ' $n$ skryf-en drukfout van die opstellers ${ }^{18}$ te make het. Omdat slegs die 5e eeuse unsiaal D dié lesing het, lyk dit korrek om Nestle-Aland se enkelvoud (oi $\alpha \alpha \nu \hat{\varphi}$ ) as die korrekte lesing te aanvaar.

Dit is opmerklik om te sien dat die bekende aanhaling van Johannes 20:21 'Net soos die Vader my gestuur het, stuur Ek julle ook', direk na die woord 'aarde' ( $\gamma \hat{\eta} s$ ), deur kodeks $\theta$ (Koridethi) en 'n paar van die Siriese Peshitta manuskripte ingesluit word. Dié lesing is egter baie duidelik 'n 'teologiese toevoeging', omdat die andet bekende en ouer manuskripte dit nie bevat nie. Eerder kan dit as 'n poging tot 'harmonisering' gesien word. Dit kan ook vermeld word dat die woord '[uit]stuur' in Johannes 20:21 se teks ook verskeie variante lesings het (vgl NA27 1995:316) en dat die opstellers nie $\dot{\alpha} \pi 0 \sigma \tau \varepsilon \lambda \lambda \omega$ verkies nie, maar eerder $\pi \dot{\varepsilon} \mu \pi \omega$.

\section{Matteus 28:19-20a}

In hierdie 'gedeelte tref ons die vermelde 'opdrag' aan. Vir talle Christene vers 19 deel uitgemaak van die 'Groot Opdrag' omdat ons hier, volgens hulle, met die 'laaste woorde van Jesus' aan sy kerk/dissipels te make het. Volgens Matteus word die dissi-

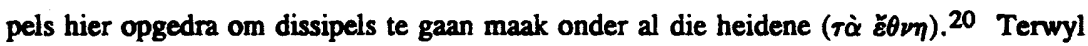
die gewone lidmaat met 'n evangeliese inslag'1 die klem normaalweg op die 'Gaan'

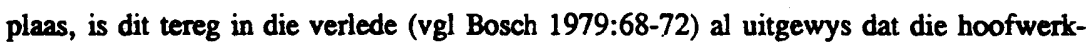

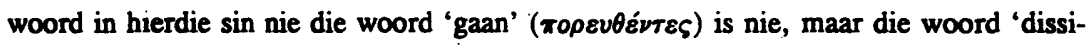
pelsmaak' ( $\left.\mu \alpha \theta_{\eta} \tau \varepsilon \dot{\sigma} \sigma \alpha \tau\right)$. 
Terwyl die woorde 'doop' en 'leer' deelwoorde (partisipiums) is, is die woord 'dissipelsmaak' 'n aoristus, imperatief aktief. Die bevel ('command') is met ander woorde nie om te gaan of te doop of te leer nie, maar 'om dissipels te maak!' Die 'dissipelsmaak' bestaan egter daarin dat 'nadat daar gegaan is', 22 word daar 'gedoop en geleer'. Aangesien die woord $\mu \alpha \theta \eta \tau \varepsilon v \sigma \alpha \tau \varepsilon$ in die aoristusvorm is, en dit nog boonop ' $n$ imperatief aktief is, kan ons daaruit aflei dat die verteller dit as ' $n$ feit stel dat dissipels aktief gemaak móét word! Alhoewel die woord $\pi \dot{\alpha} \nu \tau \alpha$ 'n hiperboliese ('oordrewe') funksie kan hê, toon dit myns insiens aan dat die verteller dit wil tuisbring dat 'niemand', met ander woorde 'geen heiden, ${ }^{23}$ oorgeslaan moet word nie.

Die manier waarop daar dissipels gemaak word, het met die doop en lering te

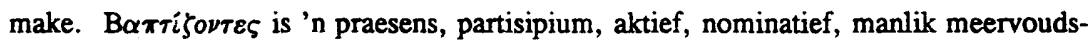
vorm van die werkwoord B $\alpha \pi \tau i \zeta \omega$. Ook die woord "leer", $\delta \iota \delta \alpha \sigma \kappa o \nu \tau \varepsilon \varsigma$, is in die praesens, partisipium, aktiewe vorm - nominatief, manlik, meervoud, afkomstig van die werkwoord $\delta \iota \delta \alpha \sigma \kappa \omega$. Opvallend is dat albei hierdie deelwoorde ondergeskik is aan die hoofwerkwoord $\mu \alpha \theta \eta \tau \varepsilon v \sigma \alpha \tau \varepsilon$ en dat albei in die praesens aktiewe vorm is.

As imperatief beheer $\mu \alpha \theta \eta \tau \varepsilon v \sigma \alpha \tau \varepsilon$ dié twee vermelde deeiwoorde ${ }^{24}$ sodat die imperatiewe (bevelskrag!) krag van dié wocrd op die woorde 'doop' en 'leer' oorgedra kan word - met ander woorde om te doop en te leer word nou ook 'n bevel! Die elf dissipels mót die heidene doop en hulle móét hulle leer! Die aktionsartliche betekenis van die praesens werkwoorde 'doop' en 'leer' is dat dit voortdurend gedoen moet word. Die aktiewe werkwoordsvorm onderstreep verder dat dissipelsmaak 'n 'aktiewe proses' is en dat die elf ${ }^{25}$ dissipels aktief daarby betrokke is en moet wees.

Die praesenswerkwoord Baxti se aktionsartliche ${ }^{26}$ betekenis is dat daar aanhoudend, aanmekaar, voortdurend, gedoop moet word. Terwyl eksegete in die meeste gevalle oor die doopsmetode swyg of dit nie bespreek nie, moontlik om 'n polemiek te vermy, is dit baie duidelik dat die bestaande Nuwe-Testamentiese leksikons of woordeboeke die doopsmetode vanuit leksikografies-semantiese perspektief as 'onderdompeling' sien. Omdat die woorde $\dot{\varepsilon} \times x \hat{\varepsilon}^{\omega} \omega$ en $\dot{\rho} \alpha \nu \tau i \zeta \omega$ onderskeidelik 'begieting' en 'besprinkeling' uitdruk, en Matteus dit nie in verband met die doopsmetode gebruik nie, maar B $\alpha \pi \tau i \zeta \zeta \omega$ hiervoor aanwend, kan dié twee metodes myns insiens nie in die lig van die Matteus-evangelie gelegitimeer word nie. ${ }^{27}$ As dit die bedoeling van Matteus was dat die doopsmetode 'begieting' of 'besprinkeling' was, dan sou hy eerder die

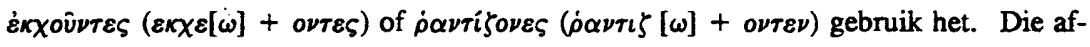
wesigheid daarvan toon duidelik aan dat dit nie sy bedoeling was nie. Van Bruggen (1974:477) het daarop gewys dat die onderdompelingsmetode wat gebruik is, van Johannes die Doper afkomstig was. Waar word mense vandag drie keer onderdompel of gedoop en nie slegs een keer nie? Met ander woorde - waarom word mense by die 
doop drie keer onder die water gedruk en nie slegs een keer nie? In die hele Nuwe Testament is dit slegs in Matteus 28:19 waar 'n grammatikale rede verskaf word!

Die anwwesigheid van die praesenswerkwoord Barri $5 \omega$ druk dit uit. Die praesenswerkwoord het 'n besliste frekwentatiewe betekenis, gedagtig aan veral die aktionsartliche betekenis. 28 Dit beteken dat iemand wat gedoop word moet voortdurend in die water gesteek word tydens die waterdoop. Die hoeveelheid kere wat daar 'geonderdompel' moet word, is egter in die dearopvolgende woorde, eij to onoma tou patroj kai tou wiou kai tou agiou pneumatoj, gelee. Die onmiddellike koteks van Matteus 28:19 spesifiseer duidelik drie afsonderlike name, te wete dié vah die Vader, die Seun en dié van die Heilige Gees. ${ }^{29}$ Dit beteken dat iemand wat gedoop word, ondendompel moet word in dié drie genoemde Name - elke keer onder die water in 'n ander Naam!

Anders gestel, as Barrifw deur Matteus in die aoristusvorm gebruik sou gewees het, dan sou hy slegs die feit dat daar gedoop moet word, aan sy leserskring wou voorgehou het, maar omdat dit nou in die praesensvorm is, spesifiseer hy uitdruklik dat daar aanmekar, sonder ophou, gedoop moet word. Sy daaropvolgende woorde cor die doop in die Naam van die Vader, Seun en Heilige Gees 'beperk' met ander woorde die elf dissipels wat moet doop dat hulle nie 'n vierde of vyfde keer 'n heiden (dié cen wat 'n dissipel gemaak word!) in die water moet onderdompel nie.

Die drie opeenvolgende genitiewe naamvalle, dit wil sê die drie bepaalde lidwoorde wat elkeen gevolg word deur 'n manlike selfstandige naamwoord, toon verder aan dat die woorde 'in die Naam van' (sis tò övoj $\alpha$ ) telkens ook voor die woord 'Seun' en 'Heilige Gees' geplaas of gelees/genoem kan word. Daar kan met ander woorde gedoop word 'In die Naam van die Vader, en die Seun, en die Heilige Gees', of 'In die. Naam van die Vader, en in die Naam van die Seun, en in die Naam van die Heilige Gees'.

Waarom wou Matteus dit hê dat daar in die Naam van die Vader, Seun en Heilige Gees gedoop moet word?30 In die Matteusevangelie (en in die hele Nuwe Testament!) is daar geen antwoord hierop nie. Slegs postulasies kan gemaak word. Myne is as volg: Die Vader het besluit om sy Seun te stuur dat Hy moet sterf ten einde die volk van hulle sondes te verlos (vgl Matt 1:21; 3:15; 11:27; 16:21,23; 17:22-23; 18:11; 20: 28; 26:31, 53; 27:46). Hierteenoor het die Seun hom vrywilliglik aan die Vader se wil onderwexp, aarde toe gekom en gesterwe sodat die mens gered kan word (Matt 3:15; $12: 50 ; 16: 21,23 ; 17: 22-23 ; 18: 11 ; 20: 28 ; 26: 31,53$ ).

Die Heilige Gees het die saligheid wat die Vader beplan het, en deur die Seun uitgewerk sou word/en is, aan die mens kom openbaar ( $v g 1$ Matt 1:18 \& 21,23; 3:15-16; $12: 18,21 ; 12: 28)$. Myns insiens het Matteus in die lig van die Ou Testament die verwysings na God die Vader, die Messias en die Gees van God probeer kombineer deur 'n 'naamformule' te skep wat 'n groter geloofwaardigheid by sy eerste lesers, wat hoofsaaklik Jode was, te/sou hê. 
Wanneer daar dan nou gedoop word in die Naam van die Vader, dan word daar erkenning gegee dat dit die Vader is wat die Seun/Messias gestuur het om God se volk te red (Matt 1:21), en wanneer daar gedoop word in die Naam van die Seun, dan word daarmee erkenning gegee dat dit die Seun is wat vrywillig gekom het om vir God se volk te sterf, en wanneer daar gedoop word in die Naam van die Heilige Gees, dan word daar erkenning gegee dat dit God is wat die Seun se koms moontlik gemaak (vgl Matt 1:18) en Hom aan die mens kom openbaar het (Matt 3:15-16; 12:18, 21; 12:28).

Die woord oiv wat in vers 19 gebruik word is resumptief of versterkend van aard en slaan terug op dit wat Matteus in vers 18 gesê het, naamlik dat 'alle mag' ( $\boldsymbol{x} \hat{\alpha} \sigma \alpha$ $\dot{\varepsilon} \xi o v \sigma i \alpha)$ in die hemel en op aarde aan Jesus gegee is. Dit beteken dat die elf dissipels na die heidene moet uitbeweeg om dissipels van hulle te gaan maak omdat alle gesag aan Jesus behoort. Dit is omdat Hy gesag het, wat Hy van die Vader ontvang het (vgl Matt 11:27), dat hulle as dissipels nou kan uitbeweeg sonder om te vrees (vgl Matt 10:16-28)!

Terwyl die twaalf dissipels voorheen, volgens die verteller, ook $\dot{\xi} \xi o v \sigma i \alpha$ van Jesus ontvang het (vgl Matt 10:1) om onreine geeste uit te dryf en siekes te genees, word daar nou geimpliseer dat $\boldsymbol{\pi} \hat{\alpha} \sigma \alpha \dot{\varepsilon} \xi o v \sigma i \alpha$ aan hulle gegee word! Hulle het nou, as die moderne spreekwoord gebruik mag word, 'n 'oop tjekrekening' om uit te beweeg en dissipels te gaan maak! Niks sal by implikasie vir hulle onmoontlik wees nie, omdat alle gesag op die aarde (ongeag waar hulle ook al geografies mag beweeg) en in die hemel aan Jesus behoort, en Hy dit weer aan hulle delegeer!

Kodeks $\mathrm{D}$ (5de eeu $\mathrm{nC}$ ) sowel as die Itala-groep manuskripte ( $\mathrm{d}$ w $\mathrm{s}$ al of die meeste van die oud-Latynse teksgetuies) het die partikel $\nu \hat{v} \nu$ pleks van oî̀. Dit betẹken dat die lesers vers 19 temporeel aan vers 18 verbind met die woorde 'Gaan dan nou en maak dissipels ....' Indien kodeks $\mathrm{D}$ gekies, word dan beteken dit vir my prakties dat die verteller wil beklemtoon dat die dissipels 'nón (onmiddellik)' moet uitbeweeg om dissipels te gaan maak omdat alle gesag aan Jesus behoort. Die huidige lesing oùv se klem is egter op die feit dat 'alle gesag' aan Jesus behoort en die dissipels daarom/vanweë hierdie gesag, moet uitbeweeg.

Myns insiens is die opstellers van $\mathrm{NA}^{27}$ se keuse van oìv die mees aanvaarbare omdat dit gerugsteun word deur 'n groot verskeidenheid van belangrike manuskripte. Dit siuit die unsiale B (Vaticanus - $4 \mathrm{e}$ eeu $\mathrm{nC}$ ), W (Washingtonensis - 5e eeu $\mathrm{nC}$ ), asook $\Delta$ en $\theta$ in. Teksfamilie 1, minuskels 33 (9e eeu $\mathrm{nC}$ ), 565 (9e eeu $\mathrm{nC}$ ), 892 (9e eeu $\mathrm{nC}$ ), 1241 (12e eeu $\mathrm{nC}$ ) en die leesroosters 844 (861/862 nC) en 2211 (995/996 $\mathrm{nC}$ ), sowel as sommige Latynse, Siriese, Sahidiese, Middel-Egiptiese en vyf of meer Bohaïriese manuskripte, het almal die lesing oùv wat aantoon dat dié lesing oor 'n wye geografiese gebied versprei was, en sterk steun gehad het, inter alia vanweë 'n gesagvolle oorsprong. 


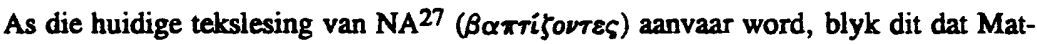
teus nie die suigelingsdoop/kinderdoop in gedagte gehad het toe hy dié vertelling van 'Jesus' aan die dissipels voorgehou het nie. Die twee praesenswerkwoorde $\beta \alpha \pi r i \zeta o \nu \tau \varepsilon \varsigma$ en $\delta i \delta a ́ \sigma k o \nu r \varepsilon \varsigma$ vind gelyktydig plaas omdat dit albei in die praesensvorm

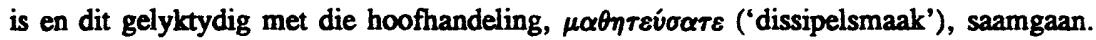
Dissipelsmaak bestaan met ander woorde daarin dat die heidene waarheen gegaan is gedoop en geleer word. Dit is nie eers doop, daarna 'n lang wagtydperk en dan word diegene wat lank terug gedoop is, geleer nie!

Omgekeerd is dit ook waar! Dit is nie eers 'n leerperiode wat deurloop word en daama as hulle alles verstaan het, word hulle gedoop nie 33 ! Met ander woorde daar is geen 'gewag' voordat daar gedoop word nie! Doop onmiddellik! Hierdie twee handelinge (doop \& leer) vind gelyk plaas. Mens maak 'n dissipel deur hom te onderdompel in die Naam van die Vader, Seun en Heilige Gees, en hom/haar te leer om alles te bewaar (mpeiv) wat Jesus sy dissipels beveel het.

Dit beteken prakties dat die persoon wat gedoop word onmiddellik geleer moet word! Dit sal suigelinge uiteraard uitsluit omdat hulle nie in staat is om geleer te word op hulle ouderdom nie. Enige heiden volwassene, selfs heiden kinders, selfs kleintjies (nie suigelinge) wat in staat is om die bevele van Jesus te verstaan en te onderhou kan en mót gedoop word. Linguisties is die twee partisipiums myns insiens hieroor duidelik genoeg.

Dit beteken egter nie dat daar volgens Matteus 'dwang' toegepas moet word met betrekking tot die maak van dissipels nie. Uit die verderliggende koteks is dit duidelik dat dissipelsskap, wat in wese die navolging van Jesus is (Pelser 1995:664-666), 'n vrywillige saak is. Met ander woorde 'n mens kies of mens Jesus wil volg of nie! Matteus stel dit baie duidelik in hoofstuk 16:24 wanneer hy van 'n voorwaarde in ('as')

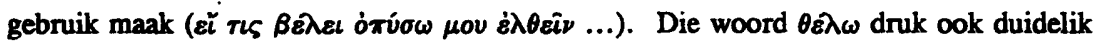
die wilskeuse uit van 'n man/vrou (rLS is manlik \& vroulik) - hy/sy self kies en be-

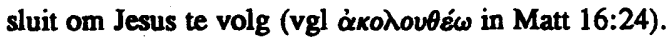

Prakties beteken dit dat Matteus bedoel het dat die elf dissipels (en by implikasie die Matteuslesers) moes uitgaan na die heidene, die Jesusverhaal aan hulle vertel moes word, en dat diegene wat positief op die boodskap reageer onmiddellik gedoop en geleer moes word. . Slegs as die heiden (volwasse of kind) die boodskap van die boodskapdraer (dws van die dissipels) 'aanvaar' (vgl Matt 10:14), word hy/sy gedoop en geleer (alles wat Jesus sy dissipels beveel het om te onderhou). Venter (1991:111) sluit min of meer aan by wat ek glo as hy sê dat 'dié wat die evangelie hoor en gunstig daarop reageer met goeie belydenis moet gedoop word in die Naam van die Drie-enige God'. 


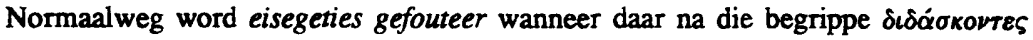

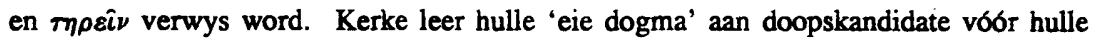
gedoop mag word en plaas hulle dikwels op 'n lang wagperiode om te sien of hulle waardig genoeg is om gedoop te word 34 , en indien die kandidaat homself/haarself 'bewys' het, dan word hy/sy gedoop. Wat presies moet aan die kandidate (meer presies die $\tau \dot{\alpha} \check{z} \theta \omega \eta$ waarvan Matteus praat!) geleer ( $\delta \iota \delta \dot{\alpha} \sigma \kappa \omega)$ word wat Jesus ${ }^{36}$ wil hê bewaar/ onderhou (mpeiv) moet word?

Die antwoord is op die oog af eenvoudig! Kyk in die Matteusverhaal wat Matteus noem Jesus aan Sy dissipels geleer en verkondig het! Enige iets méér sal eisegese wees en enige iets minder sal neologisties gesproke apogese ${ }^{37}$ wees! Wat het Jesus volgens Matteus aan Sy volgelinge geleer om te onderhou? Die lesers van die Matteusverhaal sou dadelik aan die volgende sake wat Matteus vermeld het, kon dink. ${ }^{38}$

Bekering en navolging (Matt 4:17-19), die bergpredikasie wat 'n lewe van oorvloedige geregtigheid (dws die doen van God se wil) vereis (Matt 5:20 \& 7:21), barmhartigheid (Matt 9:13), vas (Matt 9:15), gebed (Matt 9:38), prediking oor die koninkryk van die hemele (Matt 10:7), genesing, opwekking van dooies en duiweluitdrywing (Matt 10:8), 'n eenvoudige lewensstyl (Matt 10:9-10), vervolging ter wille van Jesus (Matt 10:16-22), volharding (Matt 10:22), vreesloosheid (Matt 10:26-28), God se voorsienigheid (Matt 10:29-31), die belydenis van Jesus (Matt 10:32-33), afrekening en oordeel (Matt 10:15; 11:20-24; 12:36,41-42), Jesus is Here van die Sabbat (Matt 12:8) en die lastering teen die Heilige Gees (Matt 12:32).

Daar sal ook verder gewys kan word op die korrekte begrip van die familie van God (Matt 12:50), die gemengde karakter van die koninkryk (Matt 13:30,38,47-48) en die voleinding van die eeu (Matt 13:30,39,49), rein en onrein dinge (Matt 15:2,17-20), die valse leerstellinge van die Fariseërs en Sadduseërs (Matt 16:11-12), Jesus is die Christus/Messias (Matt 16:16), die sleutels van die koninkryk (Matt 16:19 \& 18:18), eskatologiese beloning(s) vir werke (Matt 16:27), die vernaamste in die koninkryk van die hemele (Matt 18:1-14), die verpligting om te vergewe en barmhartigheid te bewys (Matt 6:14-15 \& 18: 21-35), die gronde vir egskeiding (Matt 5:32 \& 19:3-9), die seën van kindertjies (Matt 19:13-14), eskatologiese belonings vir navolging in die wedergeboorte (Matt 19:28) ${ }^{39}$, die vrymag van God se genade wat groter is as wat ons dink ${ }^{40}$, die tempelreiniging (Matt 21:12-16) en die belangrikheid van 'n onwrikbare en nietwyfelende geloof en gelowige gebed (Matt 21:21-22).

Jesus het volgens Matteus ook verwys na die doop van Johannes die Doper (Matt 21:25-32 \& 3:1-12), dat die koninkryk van God nie slegs vir Israel (Jode) is nie maar ook (eintlik ${ }^{11}$ !) vir die nie-Jode/heidene (vgl Matt 10:6;15:24,28; 21:43; 22;9; 28:19). Onderrig/lering moet ook gegee word aangaande Jesus se lering insake die verantwoor- 
delikheid om vir God en die keiser te betaal wat hulle toekom (Matt 22:21) asook Sy lering insake die groot gebod om God en die naaste lief te hê (Matt 22:37-40).

Jesus se berisping van die skrifgeleerdes en Fariseërs (Matt 23:1-39), die eindtydgebeure (Matt 24:2-25:46) en die gepaardgaande oproep om te waak teen misleiding (Matt 24:4), om te volhard (Matt 24:13), om te vlug wanneer die groot verdrukking kom (Matt 24:16-21), om waaksaam te wees tot die wederkoms (Matt 24:42 \& 25;13), en om verantwoordelik (dws om getrou en verstandig) op te tree (Matt 24:45-46 \& 25: 14-30), is alles dinge wat Matteus se Jesus geleer het.

'n Verdere deel van dit wat Jesus volgens Matteus aan Sy dissipels geleer het, sluit in die eindtydkriterium, naamlik die bewys van barmhartigheid ten einde in te kan gaan in die koninkryk van God die Vader (Matt 25:31-47). Ook word melding gemaak van die vrou wat Jesus gesalf het met kosbare salf met die oog op Sy begrafnis. Die lering sal verder ook die nagmaal moet insluit asook die feit dat Jesus aan Sy dissipels genoem het dat Hy moet ly en sterwe en opstaan (vgl Matt 16:21; 17:22-23; 20:18-19; 21 :3739). Hy het ook gesê dat hulle moet waak en bid (Matt 26:41) ${ }^{41}$.

Ná die opstanding het Hy Sy laaste opdrag aan hulle gegee, naamlik om dissipels te gaan maak deur hulle te doop en te leer (Matt 28:19)! Ook dit moet in die lering $(\delta i \delta \alpha ́ x \eta)$ wat aan die heidene gegee moet word, vervat word! Ten slotte moet die heidene ook daarop gewys word dat Matteus sê dat Jesus belowe het dat Hy met al Sy dissipels sal wees tot en met die voleinding van die eeu (dws tot en met Sy wederkoms of

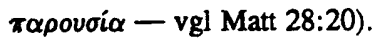

Bostaande vermelde sake toon aan wat Matteus in sy verhaal vervat het oor wat Jesus aan Sy dissipels geleer het. Dit beteken prakties dat die elf dissipels volgens Matteus self alles wat Jesus geleer het moet bewaar en só aan die heidene oordra wat ook dissipels van Hom word. Myns insiens is dit duidelik dat wat aan die elf dissipels verkondig en geleer is, deur Matteus in sy verhaal of Evangelie vervat is sodat die oorspronklike lesers (en uiteraard ook ons wat vandag lees!) kan weet wat Jesus geleer het!

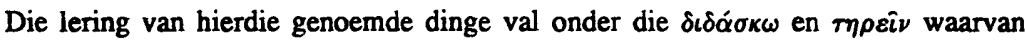

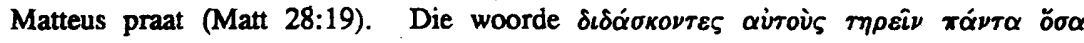

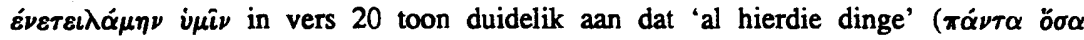
$\dot{\varepsilon} \nu \varepsilon r \varepsilon(\lambda \alpha \dot{\alpha} \mu \nu)$ vir Matteus 'alles' sou wees wat hy in sy verhaal oor Jesus se leringe aan Sy dissipels vertel het. Dit is hierdie leringe wat dan prakties deur die kerk van ons tyd aan diegene wat dissipels gemaak word geleer moet word!

Terwyl die opstellers die lesing $\beta \alpha \pi \tau i$ Yovres verkies, wat trouens ook in NA ${ }^{27}$ (vgl 1979:87) in die teks vervat is, is dit interessant en insiggewend om die wissellesing van kodekse B (Vaticanus - 4e eeu $\mathrm{nC}$ ) en D (Bezae-Cantabrigiensis - 5e eeu $\mathrm{nC}$ ) te corweeg. Dié twee unsiaalkodekse lees $\beta \alpha \pi \tau i \sigma o \nu \tau \varepsilon \varsigma$ wat 'n aoristus, partisipium, aktief, nominatief, meervoudsvorm van die werkwoord $\beta \alpha \pi \tau i \zeta \omega$ is. 
Terwyl NA ${ }^{27}$ (1979:87) hierdie teksvariant wel aangetoon het, het dit slegs in die tekskritiese apparaat vermeld dat kodekse B en D dit het. In NA ${ }^{27}$ (vgl 1995:87) word weer slegs kodekse $B$ en $D$ vermeld! Dit toon inter alia aan dat die opstellers van $\mathrm{NA}^{27}$, alhoewel hulle aanspraak daarop maak dat hulle tekskritiese apparaat meer uitgebreid as dié van NA26 is (vgl 1995:46*), dit nie altyd só is nie.

Die aoristus partisipium $\beta \alpha \pi t i \sigma o \nu T e \varsigma$ kan met die woorde 'nadat [hulle] gedoop is' vertaal word omdat dit ondergeskik is aan die hoofwerkwoord $\mu \alpha \theta \eta \tau \varepsilon v \dot{\sigma} \alpha \tau \varepsilon$. 'n Volledige dinamies-ekwivalente vertaling wat ook die aktionsartliche betekenis van die werkwoord, asook sy vox en modus na vore bring, sal dan lui: 'Nadat julle dan gegaan het, mót julle aktief dissipels van al die heidene maak, nadat julle hulle aktief gedoop het in die Naam van die Vader, en die Seun en die Heilige Gees, terwyl julle hulle voortdurend aktief leer om alles te onderhou wat Ek julle beveel het ....'

Indien hierdie lesing gekies word het die kinderdopers in die lig van die Matteusevangelie wel 'n sterk saak uit te maak dat suigelinge eers gedoop moet word, omdat dissipels eers gemaak word nadat daar klaar gedoop is! Die aoristuswerkwoord vir die 'doop', gevolg deur die praisenswerkwoord vir die 'leer", toon dit duidelik aan. Myns insiens is die keuse van die opstellers van $\mathrm{NA}^{27}$ om $\beta \alpha \pi \tau i$ 广ovres (praisens, partisipium, aktief, nominatief, manlik meervoud) as die korrekte lesing te aanvaar, korrek. Nie net kongrueer dit in die onmiddellike koteks met die ander praisens, partisipium, aktief, nominatief, manlik meervoudsvorm $\delta\llcorner\delta \alpha ́ \sigma k o v r \varepsilon \varsigma$ nie, maar ook is daar meer manuskripte wat dié lesing ondersteun.

Alhoewel $\mathrm{NA}^{27}$ nie in die tekskritiese apparaat noem watter manuskripte hulle gevolg het met betrekking tot hierdie lesing nie (vgl 1995:87), toon 'n vergelyking tussen die manuskripte wat hulle wel in die daarstelling en komposisie van die Matteus-evangelie gebruik het die volgende aan:

Van die 17 papirusmansuskripte wat hulle met betrekking tot die Matteusevangelie

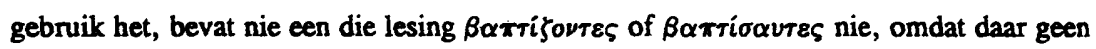
papinusmanuskrip is wat Matteus 28:19 tot 20 bevat nie (vgl NA27 1995:58*, 87, 684 689). Ten opsigte van die 41 unsiaalmanuskripte wat deur die opstellers met betrekking tot die Matteusevangelie geëvalueer is, is dit slegs 4 kodekse, te wete $\times$ (4e eeu $\mathrm{nC}$ ), W (5e eeu $\mathrm{nC}$ ), $\theta$ (9e eeu $\mathrm{nC}$ ) en 0148 (8e eeu $\mathrm{nC}$ ) wat die lesing $\beta \alpha \pi r i$ jovres het. Kodekse $B$ en $D$ is die enigste unisale wat die lesing $\beta \alpha \pi r i \sigma \alpha \nu \tau \varepsilon \varsigma$ het, terwyl die ander 35 unsiale nie Matteus 28:19 tot 20 bevat nie (vgl NA27 1995:58*, 87, 689-703).

Die minuskelmanuskripte soos teksfamilie 1 en 13, asook die Meerderheidsteks word oor die algemeen deur die kritiese geleerdes tans as chronologies 'té laat' gesien. Dit beteken dat ons keuse tussen $\beta \alpha \pi \tau i \zeta o \nu \tau e \varsigma$ en $\beta \alpha \pi \tau i \sigma \alpha \nu \tau \varepsilon \varsigma$ bepaal word deur die aanwesigheid al dan nie van dié lesings in die papiri (wat in hierdie geval ontbreek!) en 
in die unsiale manuskripte. Omdat slegs kodekse B en $\mathrm{D} \beta \alpha \pi \tau i \sigma \alpha \nu \tau \varepsilon \varsigma$ lees, en ko-

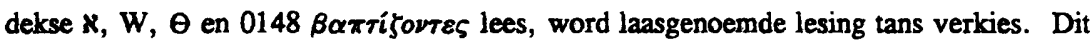

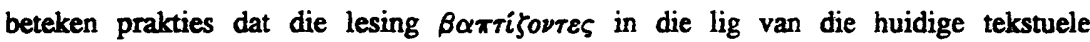
getuienisse, soos ek van mening is dat dit verstaan moet word, nie ruimte laat vir die kinderdoop nie ${ }^{43}$.

\section{Matteus 28:20b}

Matteus sluit sy verhaal af met 'n 'belofte van versekering'. Dié belofte van Jesus aan Sy elf dissipels is dat Hy met hulle sal wees - al die dae tot aan die voleinding van die eeu. Hierdie belofte is slegs vir die dissipels gegee en nie vir diegene wat Hom nie volg nie. In die onmiddellike koteks was dit slegs die dissipels wat by Jesus teenwoordig was sodat dié woorde slegs aan hulle gerig kon gewees het. Dit is myns insiens hoe Matteus dit aan sy lesers wou oorgedra het.

Die uitdrukking $\dot{\varepsilon} \gamma \dot{\omega} \mu \varepsilon \theta^{\prime} \dot{v} \mu \hat{\omega} \nu$ ei $\mu \iota^{44}$ herinner die lesers van die Matteusverhadl aan die belofte wat Matteus uit die Septuagint (Js 7:14) geneem (vgl Matt 1:23 \& NA 27 1995:3) en Christologies gaan herinterpreteer het. Dié uitdrukking 'E $\mu \alpha \alpha \nu$ ouñ $\lambda$ word deur Matteus vertaal met die woorde $\mu \varepsilon \theta^{\prime} \dot{\eta} \mu \hat{\nu} \nu$ ó $\theta e o ́ s$ (vgl NA ${ }^{27}$ 1995:3). Die aktionsartliche betekenis van ei $\mu \iota$ is dat dit voortdurende handeling uitdruk, dit wil sê Matteus wil daardeur aan die lesers beklemtoon dat Jesus voortdurend aktief by Sy dissipels teenwoordig sal wees - vanaf hierdie ontmoeting in Galilea tot en met die wederkoms!

NA27 (1995:87) het geen 'afsluiting' van die Matteusverhaal deur die gebruiklike 'amen' ( $\dot{\alpha} \mu \dot{j} \nu)$ wat so dikwels in Bybelvertalings voorkom nie (vgl die Afrikaanse 1957-naslaanbybel). Terwyl die woord $\dot{\alpha} \mu \dot{\eta} \nu$ wel deur korrektor Alexandrinus (5e eeu nC), kodeks Koridethi (9e eeu nC), teksfamilie 13, die Meerderheidsteks, die Italagroup en verskeie Vulgaat manuskripte, sowel as die Siriese en meer as 5 Bohariese manuskripte aangetoon word, word dit egter weggelaat deur die mees betroubare unsiale.

Die huidige tekslesing wat die lesing $\dot{\alpha} \dot{\mu} \dot{\eta} \nu$ weglaat is gebaseer op kodeks Alef, die corspronklike Alexandrinus, Vaticanus, Bezae-Cantabrigiensis, Washingtonensis, teksfamilie 1, minuskel 33, die leesroosters 844 en 2211, saam met 'n paar Latynse-, Siriese-, Middel-Egiptiese- en meer as 5 Bohariese manuskripte. Prakties beteken dit vir my dat die Matteusevangelie eerder die gedagte van 'n 'oop Evangelie' wil uitbeeld wat linguïsties gesproke geen 'formele afsluiting' het nie (vgl Van Aarde 1996:in toto $)^{45}$. Omdat die Matteusverhaal nog steeds oor en oor vertel word deur diegene wat deur Matteus aangespreek is, en dit nog steeds oor en oor vertel mót word, is dit duidelik dat die Matteusverhaal sonder ' $n$ slot is - ten minste tot en met die $\pi \alpha \rho o v \sigma i \alpha$ ! 


\section{Endnotas}

1 Alhoewel daar nie konsensus onder geleerdes bestann waar en wanneer die Matteusevangelie ontstann het nie (Vgl Ras 1996), is dit egter duidelik dat die meeste geleerdes 'n datering ná die val van Jerusalem in die jaar $70 \mathrm{na}$ Christus soek, in die periode van formatiewe Judaisme (vgl Van Aarde 1994: xiii-xiv; Ras 1996:32-35). In 'n resente studie se Sim (1996:i) die sosiale plasing van die Matteusgemeenskap is ma die eerste Joodse oorlog teen Rome toe dié gemeenskap in konflik gekom het met die Joodse- en heidenwêtrelde en die groter Christelike kerk [sic]. Volgens hom het die skeiding tussen die kerk en die sinngoge alreeds plansgevind omdat daar geprant word van 'my kerk' (Matt 16:18) en 'julle sinagoges' (vgl Matt 23:34). Hy is ook van mening dat die Matteusgemeenskop uit hoofsaatlik Jode bestasn het, met 'n minderheid van nie-Jode. Hierdie gemeenakap het hulleself as 'n selute bimne die formatiewe Judaisme gesion (vgl Sim 1996:208).

2 Van Aarde onderskei myns insiens tereg 3 verskillende soorte Size im Leben warmee rekening gehou moet word. Dit is die Siz im Leben Jesu, die Siz im Leben Ecclesiae en die Siz im Leben der alten Kirche (1994:6). Myns insiens kan 'n vierde een bygevoeg word, naamlik dié van die outeur self - die Sirz im Leben Auctoris. Dit verwys na die skywer se histories-kulturele situasie warin hy hom ten tyde van sy skrywe bevind het.

3 Dit is veral in die Charismatiese bewegings (Rhema) en in die Pentekostalistiese kerke (AGS, VEK, PPK) war hierdie telss met 'vuur en vlam' gepreek word ten einde lidmate an te spoor om 'moer siele' te gann wen.

4 Hiermee bedoel ek die deursnoe gelowige se siening van die 'werklike vlees- en bloed Jesus' wat as historiese persoon op die Palestynse bodem gewandel het.

5 Vergelyk byvoorbeeld die skrywe van Van Aarde (1995:325-356) rondom die sogeanamde 'Thind Quest' ma die historiese Jesus wat al verskyn het asook die roferate gelewer by die NTWSA in April 1995 by die Universiteit van Natal (Pietermaritzburg).

6 Romn Jakobeon bet gest enige teks ontstann as gevolg ven seleksie, interpretasie en kombinsaie (vgl Nidn 1983:153). Dit is ma my mening korrek. Die Mattensstorywer(s) bet geganen en 'n verhal gann sanmstel wat strek vanaf Jesus se geboorte tot en met die na-pase gebeure. Omdat dar op belnopte wyse 'n oorsig gegee word oor Jesus die Messias-Koning se leer en lewe, en dit in 'n bepalde chronologiese volgorde gegiet is, is dit duidelik dat die skrywer op selektiewe wyse sekere gebeure gann kombineer en op 'n bepaalde wyse an sy leserskring gaan voorhou het as die 'waxheid'. Dit moet ook uitgewys word dat my begrip van 'Matteus' 'n konvensionele gebruik vir die onbekende outeur van die Evangelie is (vgl Nolland 1996:463 \& Ras 1996:32).

7 Dit is tans gebruik in die NTWSA om 'n onderskeid te tref tussen die koteks en die konteks.

8 Ek gebruik tans die 3e druk van Nestle-Aland wat in 1995 verskyn het. Die cerste uitgawe van $\mathrm{NA}^{27}$ het in 1993 verskyn en is ten opsigte van die teks presies dieselfde as die 26e uitgawe. Die enigste verskille kom in die tekskritiese apparant na vore wat by $\mathrm{NA}^{27}$ meer omvattend is en die paragranindelings en punktuasie wat plek-plek anders is. Terwyl Kurt Aland, Matthew Black, 
Bruce Metzger, Allen Wikgren en Carlo Martini die hoofopstellers van NA 26 was, het dié van $\mathrm{NA}^{27}$ beataen uit Barbara Alend, Kurt Aland, Johennes Keravidopoulos, Carlo Martini en Bruce Metzger (vgl NA ${ }^{26}$ en NA 27 se inleidings).

9 Vgl Burbera en Kurt Alend (1988:83-85,102,106-107), Bruce Metzger (1968:42-48) en Kobus Petzer (1990:29-33).

$10 \mathrm{Vgl}$ die on Afriknanse 1957-nadambybel.

11 Terwyl Vm Bruggen (1990:473) ne die verskillende interpretasies verwys wat die moomtlike agtergrond van verse 16 tot 20 vorm, wys hy egter toreg daarop dat daar cerder uit Matteus se teles self afgelei moet word hoe dié verse in die Mattousvertaal inpas.

$12 \mathrm{Vgl} \mathrm{Nortje} x$ storwe oor die legende insake Judas se selfmoord (1994:41-51) en Ras (1996:323-324).

13 Dit is duidelik dat hiendie 'voorspelling' 'n Christologiese herinterpretasie van die betrokke gedeelte is rodat die locers van die Matteusevangelie moet dink dat die profoet dit werdlik in terme van die historiese tyd lank 'vooruit' al geprofetoer en dit nou bewarheid is. Hierdie tipe van interpretesie is myns insiens 'n tipiese voorboeld ven die Joodse pesjer-zotode wat ook by Qumnan in gebruik was. Ten opsigte van 'Galilea' ken die studie van E Van Eck (1995:in toto) bestudeer word. Alloewel hy die begrip 'Galilea' vamit die Markusevangelie gaan belig het, is ek ven mesing dat das baie sterk ooreenkomete tuseen Matteus se gebruik van Galilea en dif van Markus is - inter alia vamwee die anname dat Mntteus van Markus se material gebruik en verwert het (vel Ras 1996:32). Sien ook Hordey (1996:88-104) vir resente opmerkings oor die 'verhoudine' tuseen Galilea en Jeruscilem.

14 Harrington (1991:414) bet tereg gead dat dit 'pointloss' is om te spelaleer watter berg hier bedoel word (vgl ook Morris 1992:744 \& Nielsen 1974:188). Volgens Son (1983:64) is die 'berg' in Mmteas die plek want Jesus sy goddelike gecag openbaar. Die volgande berge is egter al genoem: Die berg van versocking (Matt 4:8), die berg van die bergrode (Matt 5:1), die berg van gebed (Mat 14:23), die berg van genesing (Matt 15:29-31) en die berg van verhoerliking (Matt 17:1). Sien cok Ras (1996:212). Nielsen het myns insiens tereg opgemerk dat dit geen sin bet om die berg op te spoor nie, behatwe vir toerisme doeleindes (vgl 1974:188). Waetjen (1974:254) st niks oor die berg nie. Son (1963:64) het daurop gowys dat die berg in Galilea (Matt 28:16) simbo-lies die plek is war die Verbondsgod Sy 'volk' ontmoet vir die verklaring van Sy wil en Sy doel met mulle.

15 Markus 16:9-21 word deur die meeste geleerdes vanwee tekskritiese redes nie annvar nie inter alia vanweè die afwesigheid van dié teksgedeelte in die belangrikste unsiale manuskripte ecos Alef en Vaticamus (vgl NA 27 1995:148-149 \& Vorster 1980:125-126).

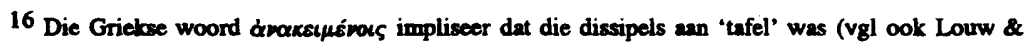
Nida 1988:218-219). 


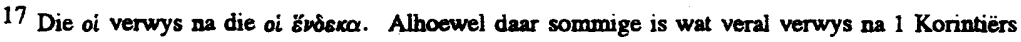
15:6 se verwysing na Jesus se verskyning an oor die 500 broeders tegelyk, en daarmee wil impljseer/sê dat dar meer as 11 dissipeis by hierdie ontmoeting in Galilea met Jesus was, is dit vir my duidelik dat die onmiddeliike koteks slegs van die 11 dissipels praat (vgl Matt 28:16; Son 1983:65 \& Watson 1992:87).

18 Horst Bachmann en Gustav Wendt was die proeflesers van NA 27 terwyl die tekskritiese apparaat hersien is deur Klaus Witte. Die data insake die papiri en unsiale is deur Wolfgang Richter en Klaws Wachtel gedoen en die lys van manuskripte is uitgebrei en geverifieer deur Michael Welte (vgl NA 27 1995:Foreword \& 48* waar die opstellers wel kodeks D (05) en kodeks D (06) uiteensit maar die leser nog steeds in onsekerheid bly oor wat hulle presies daarmoe bedoel).

19 Myns insiens sou die uitdrukking 'hemele' (meervoud) aan die Joodse gedagte, dat daar 3 verskillende soorte hemele was (vgl 2 Kor 12:2), verbind kon word. Die cerste hemel is normalweg as die wolkehemel beskou, die tweede as die verder liggende sterrehemel, en die derde hemel dié plek waar God en die engele is. Indien 'hemele' in vers 18 was sou dit dan beteken het dat alle gesag wat in aldrie hierdie hemele is, an Jesus gegee is. Ten opsigte van kodeks D het Panten (1996:187) in seker cen van die mees omvattende en resente studies daarop gewys dat dié unsiale manuskrip tussen 350 tot $450 \mathrm{nC}$ gedateer moet word en dat D se oorsprong in die ooste, moontlik Egipte, alhoewel Siriè en Jerusalem nie uitgesluit is nie, lê. Beiroet is egter uitgesluit.

20 Die Jode het alle nie-Jode as heidene beskou en die Christene het weer alle nie-Christene as heidene beskou. Alhoewel hierdie uitdrukling ook 'nasies' kan beteken, is dit myns insiens dujdelik genoeg dat Matteus bedoel het dat diegene wat dissipels gemaak moet word, diegene is wat nog nie volgelinge van Jesus is nie. Terwyl Harrington (1991:414-415) die vraag vra of die rò $80 \mathrm{~m}$ slegs na die heidene (nie-Jode) verwys en nie ook na die Jode self nie, is daar al meer konsensus dat dit die Jode cok insluit (vgl Nielsen 1974:192; Sim 1996:171; Van Aarde 1994:13).

21 Hiermee word bedoel Christene wat hulleself as 'siele-wenners' beskou. Dié tipe van uitdrukking is alombekend in Pinkster- on Charismatiese kringe asook in die sogenamde 'Heiligheidsbewegings' soos die AEB (Afrika-Evangeliese Bond).

22 Die woord xasuećntes is 'n aoristus partisipium passief wat tereg met 'nadat [julle] gegaan het', vertal kan word.

23 Met 'beiden' bedoel ek hier 'elke mens' wat nog nie 'n dissipel van Jesus (die Messias) is nie (vgl ook Watson 1992:68).

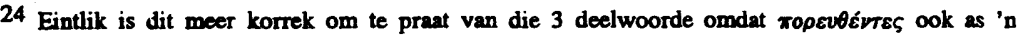
soristus partisipium hierby ingesiuit word.

25 Dit is belangrik om dearop te let dat die Matteusverhaal 'n boodskap bevat insake Jesus wat myns insiens oorspronklik in terme van die historiese tyd aan die 'pre-paschal disciples' gerig 
was, maar wat nou ook in terme van die verhaltyd van Matteus an die 'post-paschal disciples' gerig word. Dit beteken pralties dat mie slegs die corspronklike elf dissipels moes uitgaan om dissipels te gam maak mie, mar ook die censte lesers an wie die Matteusverhal gerig was, en by implikasie ook ons wat vandag die Matteusverhal lees.

26 Vergelyk die studie van G Van Wyk Kruger (1981:in toto) insake die aktionsart van die NuweTestamentiese verbum.

27 Woordretoriek en semantiese 'speletjies' om dié basiese betekenis van Boxri spreek' sodat dit ook ruimte moet last vir die ander twee doopsmetodes is met betrekking tot die Mattensevangelie mie talkoundig begrond en deurdink mie. Myns insiens word dié sieninge cerder kertilik konfessioneel en/of dogmaties veranker as op Nuwe-Testamentiese en eksegetiese gronde. Vergelyk inter alia Abbott-Smith (1977:74-75) en Arndt en Gingrich (1979:131-133) oor die betekenis van Borrofifw. Louw en Nida (1988:537-538) se semantiese opmerkjuge insake Barrifw is baie skraal en verrani 'n 'teologiese ongemak' met die onderdompelingsmetode. Hulle enigste verwysing ma die metode is 'n opmerking dat die Didache in die $2 e$ etu $\mathrm{nC}$ dit verkies het. Di6 opmerking insake die Didache (vgl hfs 7 \& Pretorius 1980:19) is egter irrelevant met betrekking tot die doopsmetode in die Matteusevangelie (en die res van die Nuwe Testament) omdat die Didache heolwat later ontstaen het (vgl Pretorius 1980:2-3 \&9-10). Louw en Nida self dateer dit vroeg in die 20 ceu nC (vgl 1988:538).

28 Vergelyk Kruger (1981:25) ssook die tradisionele leksikon van Joseph Henry Thayer (sa:94) wat myns insiens beslis mie 'uitgedien' is nie, mar tereg krities-evaluerend gebruik moet word. Louw en Nida se bekende leksikon (1988:536-538) vermeld niks hieroor nie.

29 Dit is interessant dat bierdie die enigste geval in die hele Matteusvertaal en in die Nuwe Testament is wasr die Nam van die 'Drio-eenheid' an die doopsmetode verbind word. Nielsen (1974:194) dat die kerkvader Eusebius van Cesarea (wat $339 \mathrm{nC}$ gesterf het) voor $325 \mathrm{nC}$ die teks sonder die doopopdrag asahnal as 'Maak al die volke tot My dissipels in My Naam.' Ná die Konailie van Nicea (325 nC) gebruik by die Naam van die Drie-eenheid in plans van 'in My Nanm'. Schweizer (1975:530) bet gese dat Eusebius die uitdrukking 'in My Nasm' 21 keer voor Nicea gesiteer bet en dat die byvoeging van die drie Name 'n latere ontwikkeling verteenwoordig. Alhoewel Harrington (1991:415) na die Didache (hfs 7:1-3) verwys ten einde die 'Drie-enige doop' te 'logitimeer', is sy opmerking en verwysing myns insiens onvanpas omdat die Didache later as die Mattousevangelie ontstann het/gedatcer word (vgl Prrtorius 1981).

39 Hierdie vrang vra ok as 'n gelowige wat in die twintigste eeu eksistensiele betekenis soek oor die betekenis ven my doop - net 000 talle ander gelowiges.

31 Dit is opvallend dat die woord 'volk' kotekstweel uiteraard op die Joodse volk Israel dui (vgl Matt 1:21; 2:2; 10:6 \& 15:24) en dat Matteus 1:21 spesifiek nie die nio-Jode insluit mie. Dit word cers later na vore gebring (vgl bv Matt 21:43). Opvallend is dat die Siriese Curetonianns

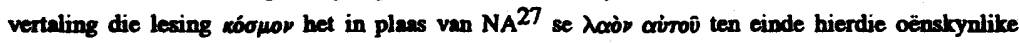
crux vir die lesers in perspeltief to plass. 
32 Hier kan veral an die tradisionele Gereformeerde kerke gedink word wat later op min of meer 16 tot 18 jarige leeftyd van die gedoopte kind 'n belydenis van geloof ná 'n lang 'katkisasie' vereis ten einde as volwardige lidmaat in die gemeente opgeneem te kan word.

33 Die Anabaptistiese-, Pinkster- en Charismatiese groepe is hier tipiese voorbeelde. Roy en König (1996:400) het tereg dié manier van 'doen' gekritiseer.

34 Kerke wat die 'gelowige doop' (wat dikwels deur kinderdopers verkeerdelik as 'volwasse doop' beskou word omdat hulle nie die 'gelowige doop' werklik wil erken nie) beofen maak hulle veral hieraan stouldig.

35 Tipiese voorbeelde is dié in die AGS, VEK en PPK waar mense deur die jare byvoorbeeld na sy/haar bekering cers 'dopgehou' is om te sien of die betrokkene werklik sy 'rokery', 'drank', 'dans' en een of ander uiterlike sonde gelos het voor hy/sy gedoop mag word. Die kandidaat moet homself/haarself gevolglik 'uiterlik bewys' dat hy/sy waardig genoeg is om gedoop te word. Hierdie 'bewys' van 'oorwinning oor sonde' word egter nie as 'werke' getipeer in die kringe nie.

${ }^{36}$ Met 'Jesus' bedoel ek Matteus se 'gerekonstrueerde Jesus' wat hy aan die lesers voorgehou het.

37 Met 'apogese' bedoel ek dat iemand iets uitlaat wat wel gesé moet word. Dit is afkomstig van

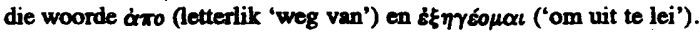

38 Alhoewel 'n mens op die letter af in die lig van Matteus 28:19-20a kan st dat dit slegs die imperatiewe of bevele is van Jesus wat geleer moet word, is dit myns insiens té simplisties. Talle leringe en bevele is vervat in stellinge en gelykenisse wat nie direk in Matteus se Evangelie in 'n imperatiewe vorm gestel is nie.

39 Ek stem sanm met NA ${ }^{26}$ (1979:54) en NA ${ }^{27}$ (1995:54) dat die komma na die woorde غ̇ गn

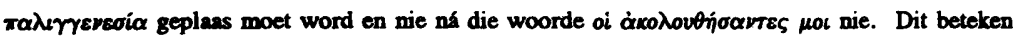
prakties dat die begrip 'wedergeboorte' nie op 'n kosmiese vernuwing/wedergeboorte dui nie, maar dat dit aan die navolging van Jesus verbind word - dit wil sê Matteus bedoel: "Voorwaar Ek sê vir julle, dat julle wat my in die wedergeboorte gevolg bet [KOMMA!], wanneer die Seun van die mens ....' Dit beteken prakties dat mens Jesus in die wedergeboorte (wat met saligheid te make het) volg.

40 Hierdie kontroversiële gelykenis wat verskillende interpretasies het, stan myns insiens in verband met die gratia Dei (vgl Ras 1996:149-150 \& 207-208). Kotekstueel het dit te make met die ingaan in die koninkryk van God en toon dit op simplistiese wyse vir my dat God almal dieselfde saligheid of redding gee, ongeag op wattter spesifieke tydstip hulle (d i die arbeiders wat elke mens voorstel) na Hom toe gekom het om 'gered' (volgens die gelykenis het hulle kom 'werk vra') te word. Vergelyk Jones se opsomming van al dié skrywes oor dié gedeclte (1995:568-569).

41 Dit is algemoen bekend dat die heil vir Matteus nie partikularisties (vir die Jode alloen) is nie, mar universalisties (ook vir die nie-Jode) - veral Matteus 21:43 word as die draxipunt in die Matteusverhal beskou wat hierdie gedagte sterk na vore bring (vgl Combrink 1980:63-64, 95-96 \& 101). 
42 In hierdie spesifieke geval het Jesus dit volgens Matteus slegs vir Petrus en die twee seuns van Sebedeus gese (vgl Matt 26:37). Die lesers kon hierdie teks (Matt 21:41) egter op spiritualistiese wyse ook op hullecelf van toepassing gemaak het sodat die dissipelkring groter is as slegs die oorspronklike drie.

43 In 1984 het ek as teologiese student myself die vraag afgevra of die lesing Barriourres in spesifiek kodeks Vaticanus (Vgl NA26 1979:87) nie 'n teksiesing was wat spesial geskep is om die gedagto van die suigelingsdoop in die lig van die Skrif te gaan 'legitimeer' nie. Ek het tot op hede nog nooit dié moontlikheid verder gaan ondersoek nie, alhoewel ek wonder of die RoomsKatolieke nie tans veel meer van dié lesing sal makk nie. Dit is ook opvallend om te sien dat die meeste verklaarders geen bespreking van dié twee wissellesings gee (vgl o a Morris 1992:748-749 \& Son 1983:168).

44 Unsiale $K$ en $D$ het die presiese woorde mar nie dieselfde woordvolgorde as NA 27 nie.

45 Van Aarde het myns insiens tereg die stelling gemaak en indirek op teologiese gronde uitgewys dat die Matteusevangelie 'n 'oop Evangelie' is.

\section{Literatuurverwysings}

Abbott-Smith, G 1977. A manual Greek Lexicon of the New Testament. Latest ed. Edinburgh: T \& T Clark.

Aland, B, Aland, K, Karavidopoulos, J, Martini, C M \& Metzger, B M 1995. Novum Testamentum Graece. 27 revidierte Auflage. 3.Druck. Stuttgart: Deutsche Bibelgesellschaft.

Aland, K, Black, M, Martini, C M, Metzger, B M \& Wikgren, A 1979. Novum Testamentum Graece. Ed XXVI. Stuttgart: Deutsche Bibelgesellschaft.

Arndt, W F \& Gingrich, F W 1979. A Greek-English lexicon of the New Testament and other early Christian literature. 2nd ed. Chicago: The University of Chicago Press.

Bosch, D J 1979. Heil vir die wereld: Die Christelike sending in teologiese perspektief. Pretoria: NG Kerkboekhandel.

Combrink, H J B 1980. Die Evangelie volgens Matteus: Inleiding en teologie in Du Toit, A B (red), Handleiding by die Nuwe Testainent, IV. Die Sinoptiese Evangelies en Handelinge: Inleiding en Teologie. Pretoria: NG Kerkboekhandel.

Garland, D E 1993. Reading Matthew. A literary and theological commentary on the First Gospel. London: SPCK.

Harrington, D J 1991. The Gaspel of Matthew, Vol 1. Sacra Pagina Series. Collegeville, Minnesota: The Liturgical Press.

Horsley, R A 1996. What has Galilee to do with Jerusalem? Political aspects of the Jesus movement. HTS 52/1, 88-104. 
Jones, I H 1995. The Matthean parables: A literary and historical commentary. Leiden: E J Brill.

Joubert, S 1994. Matteus vandag: Die Woord vir die mense. Halfway House: Orion Uitgewers.

Kingsbury, J D [1986,1988] 1989. Matthew as story. Revised and enlarged. Second print. Philadelphia: Fortress.

1995. The rhetoric of comprehension in the Gospel of Matthew. NTS 41/3, 358-377.

Kruger, G Van Wyk 1981. Die teorie en eksegese van die Nuwe-Testamentiese verbum. Stellenbosch: UUB Uitgewers.

Laytner, A 1996. Christianity and Judaism: Old history: New beginnings. Journal of Ecumenical Studies 33/2, 187-203.

Louw, J P \& Nida, E 1988. A Greek-English lexicon based on semantic domains, Vols I \& II. New York: UBS.

Metzger, B M 1979. The text of the New Testament. Its transmission, corruption and restoration. Oxford: At the Clarendon Press.

Morris, L 1992. The Gospel according to Matthew. Grand Rapids, MI: Eerdmans.

Nida, E A, Louw, J P, Snyman, A H \& Cronje, J v W 1983. Style and discourse: With special reference to the text of the New Testament. Cape Town: Bible Society.

Nielsen, J N 1974. Het Evangelie naar Mattheïs, In. Nijkerk: G F Callenbach B V.

Nolland, J 1996. Genesis in Matthew 1:1. NTS 42/3, 463-471.

Nortjé, L 1994. Matthew's motive for the composition of the story of Judas's suicide in Matthew 27:3-10. Neotestamentica 28/1, 41-51.

Panten, K E 1996. A history of research on Codex Bezae. Tyndale Bulletin 47/1, 185187.

Pelser, G M M 1995. Die kerk in die Nuwe Testament. HTS 51/3, 645-676.

Petzer, K 1990. Die teks van die Nuwe Testament: 'n Inleiding in die basiese aspekte van die teorie en praktyk van die tekskritiek van die Nuwe Testament. HTS, Suppl 2. (Reeksred A G Van Aarde). Pretoria: Gutenberg Boekdrukkers.

Pretorius, N F 1981. Die Didaché: Die ondenwysing van die maalf apostels. Kaapstad: NGK Uitgewers.

Ras, J M 1996. Die wederkoms van Christus in die Matteusevangelie: 'n Literêr-kritiese (narratiewe) studie. DTh-proefskrif, Universiteit van Stellenbosch.

Roy, K \& König, A 1996. So which is the right baptism? NGTT 37/3, 396-403.

Schweizer, E 1975. The Good News according to Matthew, tr by D E Green. Atlanta, GA: John Knox. 
Sim, D C 1996. Apocalyptic eschatology in the Gospel of Matthew. Cambridge: Cambridge University Press.

Son, Y J 1983. The missiological significance of Matthew 28:16-20 with special reference to Donald McGavran. DTh-dissertation, University of Potchefstroom for Christian Higher Education.

Thayer, J H [s a]. A Greek-English Lexicon of the New Testament. Latest ed. Grand Rapids, MI: Zondervan Publishing House.

Van Aarde, A G 1994. God-with-us. The dominant perspective in Matthew's Story and other essays. HTS, Suppl 5. (Series ed: AG Van Aarde). Pretoria: Gutenberg Press.

1995. The 'third quest' for the historical Jesus - where shall it begin: With Jesus' relationship to the Baptiser, or with the nativity traditions? Neotestamentica 29/2, 325-356.

1996. The First Testament in the Gospel of Matthew. Unpublished paper presented at the NTSSA, 9-12 April 1996, University of Pretoria.

Van Bruggen, J 1990. Matteus: Het evangelie voor Isräel. Kampen: J H Kok.

Venter, J 1991. Soeklig: Fokus op Matteus. 'n Bybelstudiegids vir jongmense. Potchefstroom: Herald Drukkery.

Vorster, W S 1980. Die Evangelie volgens Markus: Inleiding en teologie in Du Toit, A B (red), Handleiding by die Nuwe Testament, IV: Die Sinoptiese Evangelies en Handelinge: Inleiding en Teologie. Pretoria: NG Kerkboekhandel.

Waetjen, H C 1976. The origin and destiny of humanness. An interpretation of the Gospel according to Matthew. San Rafael, CA: Crystal Press.

Watson, D C C [s a] 1992. The Gospel according to Matthew. Cambridge: University Printing Services. 